\title{
Measuring offshore tsunami currents using ship navigation records
}

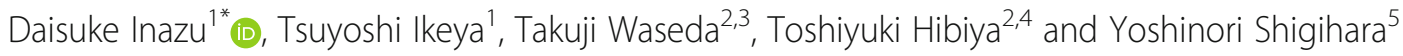

\begin{abstract}
We investigated ship navigation records known as Automatic Identification System (AIS) data near the source region of the 2011 Tohoku, Japan, tsunami. The AIS data of 16 ships in the offshore navigation could be compiled by about 40 min after the tsunami generation. Most of the AIS data showed notable deviation of the ship heading from the course over ground during the tsunami passage. There was good agreement in terms of amplitude/phase between the ship velocity and the simulated tsunami velocity in the direction normal to the ship heading. An equation of motion due to wave drag and inertia forces was examined for an offshore movable floating body. We explain that the ship movement in the direction normal to the heading immediately responds to the tsunami current, and relative velocity between the ship and the tsunami current asymptotically become zero. This indicates the movement velocity of navigating ships in the direction normal to the heading derived from AlS data will work as an offshore tsunami current meter. We examined the AIS data during the 2011 Tohoku tsunami and showed these data could be useful for tsunami source estimation and forecast. The AIS data in the current framework will possibly be a crowd-sourced tool for monitoring offshore tsunami current and tsunami forecast.
\end{abstract}

Keywords: Tsunami current, Automatic identification system (AIS), Navigating ship

\section{Introduction}

Great earthquakes and tsunamis have caused significant loss of life and property in coastal communities (ITIC 2015). In the 2004 Sumatra-Andaman, Indonesia, earthquake and the 2011 Tohoku, Japan, earthquake, most casualties (200,000 for the 2004 disaster and 20,000 for the 2011 disaster) were caused by the flooding due to the tsunamis (Satake 2014). Coastal mega cities have to prepare to reduce these losses especially from the tsunamis. In addition to constructing proper embankments in advance of earthquake and tsunami occurrences (Tomita et al. 2012; Suppasri et al. 2013; Raby et al. 2015), immediate actions of individuals and groups after the earthquake/tsunami occurrences are critical for reducing significant, early-stage loss of life (Mas et al. 2013; Makinoshima et al. 2016).

Real-time forecasting of great earthquakes and tsunamis can be utilized for suitable decision-making for disaster mitigation. Real-time forecast systems should be robust and reliable. Current systems are based on real-time Earth

\footnotetext{
* Correspondence: inazud@m.kaiyodai.ac.jp

${ }^{1}$ Department of Marine Resources and Energy, Tokyo University of Marine Science and Technology, 4-5-7 Konan, Minato, Tokyo 108-8477, Japan Full list of author information is available at the end of the article
}

monitoring that uses onshore and offshore observations. These observations include seismic waves (Allen et al. 2009; Kamigaichi 2009), crustal deformation (Sagiya 2004; Ruhl et al. 2017), and offshore sea level or the tsunami itself (Falck et al. 2010; Kawai et al. 2013; Rabinovich and Eblé 2015).

Rapid earthquake-source estimation systems using seismic-wave observations are popular. However, these methods estimate a point source that may be indirectly related to tsunamis, and are somehow difficult to accurately constrain the tsunami source dimension particularly for great earthquakes (Katsumata et al. 2013; Hoshiba and Ozaki 2014). Earthquake-source estimation using Global Positioning System/Global Navigation Satellite System (GPS/GNSS) observations of land deformation will suitably constrain the source dimension with moment magnitude of nearshore $(<100 \mathrm{~km}$ from the coast) earthquakes (Melgar and Bock 2015; Kawamoto et al. 2017). For greater earthquakes $\left(M_{\mathrm{w}}>\right.$ 8.5), in addition to the fault slip, seafloor failure due to strong ground motion likely causes a certain portion of tsunami (Kawamura et al. 2014; Løvholt et al. 2015). It is better to use direct observations of offshore sea level to estimate the resultant tsunami size. 
Real-time forecasting of great tsunamis based on offshore tsunami observations has been popular. The tsunami forecast system using the Deep-ocean Assessment and Reporting of Tsunamis (DART) buoys is well known (Wei et al. 2013; Tang et al. 2016). The Japan Meteorological Agency (JMA) developed a tsunami forecast system using cabled seafloor pressure and GPS-buoy observations (Tsushima et al. 2011, 2012). These forecast systems will be enhanced using real-time geodetic monitoring as well (Tsushima et al. 2014; Wei et al. 2014). Forecast methods using very dense seafloor observation networks have been also proposed independently (Maeda et al. 2015; Igarashi et al. 2016; Yamamoto et al. 2016). These forecast systems using offshore tsunami observations will be robust and reliable.

The observatories have to be maintained and sustained at least until the next devastating tsunami. Such an event may occur once typically during tens to hundreds of years at a certain place (McCaffrey 2008; Rong et al. 2014). In general, offshore observatories require higher maintenance costs than onshore observatories, and replacements will be necessary after endurance periods, typically several decades after installation (Hirata et al. 2009). Tsunami forecast methods especially measurement systems need sustainability as well as reliability (NRC 2011; Bernard and Titov 2015). It is desirable to propose and develop other sustainable methods of monitoring and forecasting of great tsunamis.

Tsunami as sea-level change could be detected by shipborne GPS. A $10 \mathrm{~cm}$ tsunami caused by the 2010 Maule, Chile, earthquake was detected by a vertical position change derived from high-precision GPS of a navigating ship (Foster et al. 2012). This indicates that navigating ship networks will serve as offshore tsunami observation networks (Inazu et al. 2016). However, this requires high-precision GPS facilities on most of the vessels to precisely measure their positions as well as GPS buoys (Terada et al. 2015). On the other hand, ship positions are currently aggregated as the Automatic Identification System (AIS) data under International Maritime Organization (IMO) regulations (IMO 2002; Earles et al. 2010). The ship positions in the AIS data do not include vertical position, and they are mostly measured by ordinary GPS with meter-order precision which is employed in ordinary car navigation. Therefore, if we employ ship GPS/AIS data to measure tsunami height, it is necessary to update current facilities so as to estimate the high-precision locations of almost all of the vessels and modify the regulations of the IMO.

During the 2011 Tohoku tsunami, a number of vessels in ports drifted significantly and collisions occurred due to strong tsunami currents (Suga et al. 2013; Suppasri et al. 2014; Matsuda and Tomita 2015). The behaviors of the ship horizontal drifts with collision in a port were examined using AIS data with tsunami simulation (Matsuda et al. 2012). The ship drifts should be affected by tsunami currents; however, the relationship between them still seems unclear due to a complicated situation in the port. On the other hand, AIS data were also available in offshore regions during the tsunami. It was reported that movement directions of several offshore ships deviated during the tsunami (Makino 2013; Liu et al. 2015). However, these reports merely showed the facts and hardly described any quantitative relationship between the deviations and the tsunami. There is still much room to be clarified regarding the expected relationship between ship drifts and tsunamis.

In the present study, we examine the AIS records of multiple ships navigating near the source region of the 2011 Tohoku tsunami. The relationship is investigated quantitatively between the ship horizontal movement or drift and the tsunami current. We describe the usefulness of the AIS data to measure offshore tsunami currents and to be applied to tsunami forecast.

\section{AIS data}

We can browse almost real-time ship distributions derived from AIS data on web sites such as MarineTraffic (https:// www.marinetraffic.com/). According to the IMO regulations, ships exceeding 300 gross tonnage and all passenger ships have to send their AIS information via very-high-frequency (VHF) radio transmission (Tetley and Calcutt 2001; IMO 2002). The AIS data include dynamic and static information. The dynamic information includes latitude/longitude (without vertical height), speed over ground (SOG), course over ground (COG), and ship heading (HDG). The static information includes draft, Maritime Mobile Service Identity (MMSI), ship type, and ship name. The AIS data from nearshore vessels $(<\sim 100 \mathrm{~km}$ from coast) are received by coastal stations, and those from ships farther offshore can be also received by low-Earth-orbit satellites such as ORBCOMM (Carson-Jackson 2012). The number of ships recognized with AIS data is increasing year by year with increasing seaborne trade and number of satellites (Tournadre 2014; Willick 2014).

\section{Ship distributions during the Tohoku tsunami}

The 2011 Tohoku earthquake occurred at 05:46 (UTC) on 11 March 2011, and the resultant tsunami reached the coasts with significant wave heights $(>10 \mathrm{~m})$ 40-60 min after the tsunami generation (Tsushima et al. 2011; Wei et al. 2013; Saito et al. 2014). The tsunami currents were expected to be greater than $1 \mathrm{~m} / \mathrm{s}$ near the coastal areas where sea depth is shallower than $200 \mathrm{~m}$ (Sugawara and Goto 2012). Our tsunami simulation also shows such tsunami heights and currents (Fig. 1). Due to such strong tsunami currents, as mentioned above, a number of vessels in the ports drifted significantly, resulting in collisions and severe damages to buildings and structures there. On the other hand, there were actually many offshore vessels navigating 


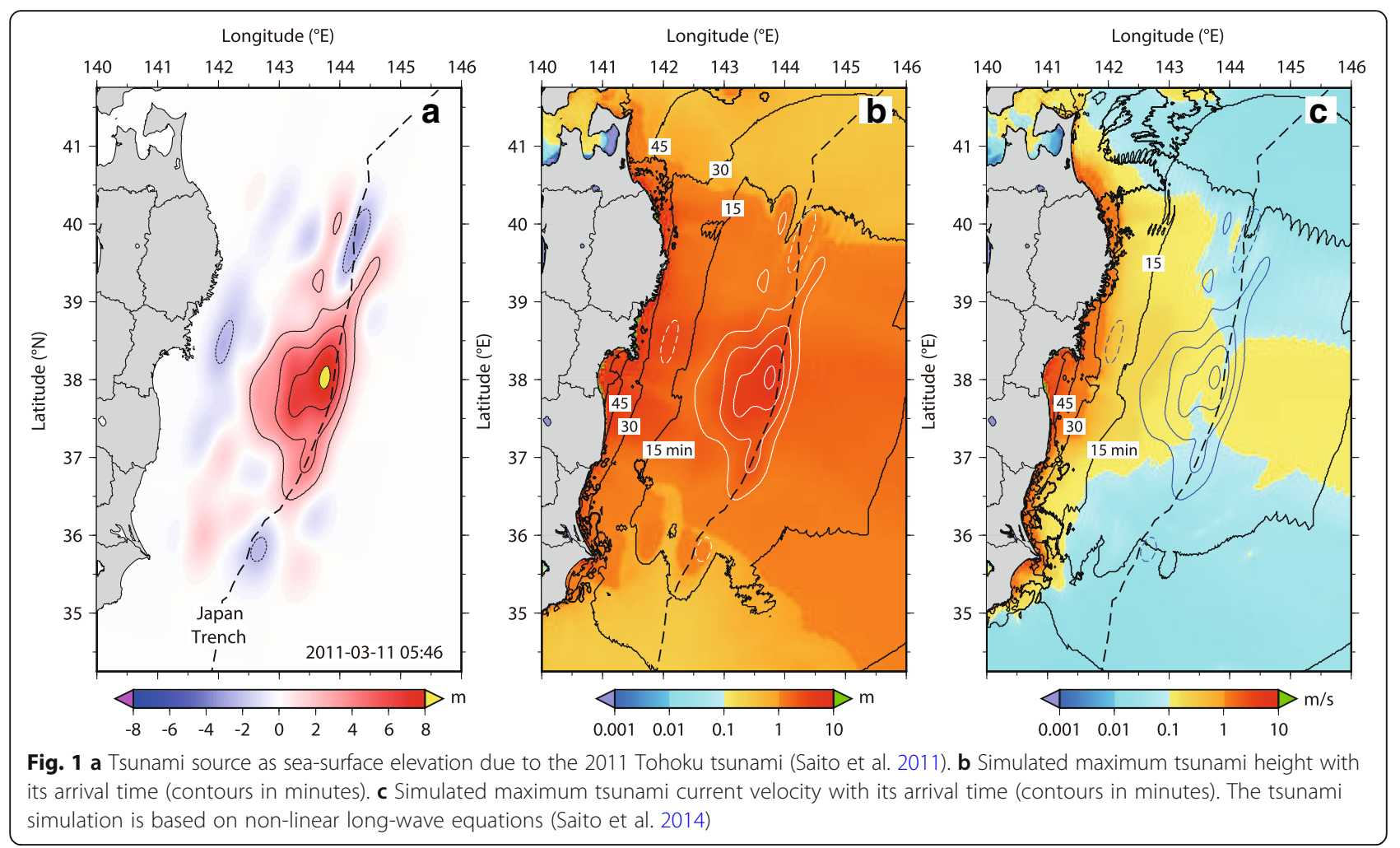

near the earthquake/tsunami source. Just after the earthquake occurrence, although most of the AIS data offshore of Miyagi were lost because coastal stations failed to receive the AIS data probably due to near-source strong ground motion, some data were obtained until the tsunami devastated the coast (Fig. 2). The offshore navigating ships probably experienced tsunami currents of around $1 \mathrm{~m} / \mathrm{s}$ (Fig. 1).

\section{Ship drifting and tsunami current AIS records}

It was found that AIS messages were successfully received from 16 vessels in offshore regions (depth > $100 \mathrm{~m}$ ) during about $40 \mathrm{~min}$ after the earthquake occurrence. These ships were typical commercial ships such as cargo ships and tankers. In the present study, the AIS data of 13 vessels (\#1-\#13) were used for the tsunami analysis, and 3 other vessels ("1-"3) were not used due to data quality issues (Fig. 2 and Table 1).

We examined the speed over ground (SOG), the course over ground (COG), and the heading (HDG) of the offshore ships (Fig. 3). COG is the direction of true ship movement. HDG denotes the direction of ship heading that is measured by an ordinary magnetic/gyro compass. SOG and COG are measured by the time evolution of ordinary GNSS positioning. Though COG and HDG are expected to be consistent under normal weather/ocean conditions, it was reported that there were significant deviations between
COG and HDG during this tsunami as mentioned above (Makino 2013; Liu et al. 2015).

We show examples of time evolution of AIS records of navigating ships (Fig. 4). One ship offshore of Iwate (\#3) was moving northward $\left(\mathrm{HDG} \sim 10^{\circ}\right.$ ) before and after the earthquake occurrence. Just after the earthquake, the captain may have reduced the ship velocity (from 6.8 to $5.7 \mathrm{~m} / \mathrm{s}$ ) probably because of receiving an early tsunami warning. Although there was no significant deviation between COG and HDG until $15 \mathrm{~min}$ after the earthquake, there was significant deviation $\left(>5^{\circ}\right)$ after that. Another ship offshore of Fukushima (\#5) was moving southward $\left(\mathrm{HDG} \sim 185^{\circ}\right)$. While this ship was going with constant speed $(\sim 6.0 \mathrm{~m} / \mathrm{s})$ during this earthquake and tsunami, the deviation between COG and HDG was evident $\left(>5^{\circ}\right)$ after $20 \mathrm{~min}$ after the earthquake. Other examples that were used or not for the analysis are shown in Additional file 1: Figure S1.

We investigate the relationship between the deviation and the tsunami current. Ship propulsion during ordinary offshore navigation is imposed mostly in the HDG direction. The deviation between COG and HDG is reasonably caused by the normal component of external force against the HDG. Here, ship velocity and tsunami current are examined in the direction normal to the HDG (Fig. 3).

The ship velocity component in the direction normal to the HDG is: 

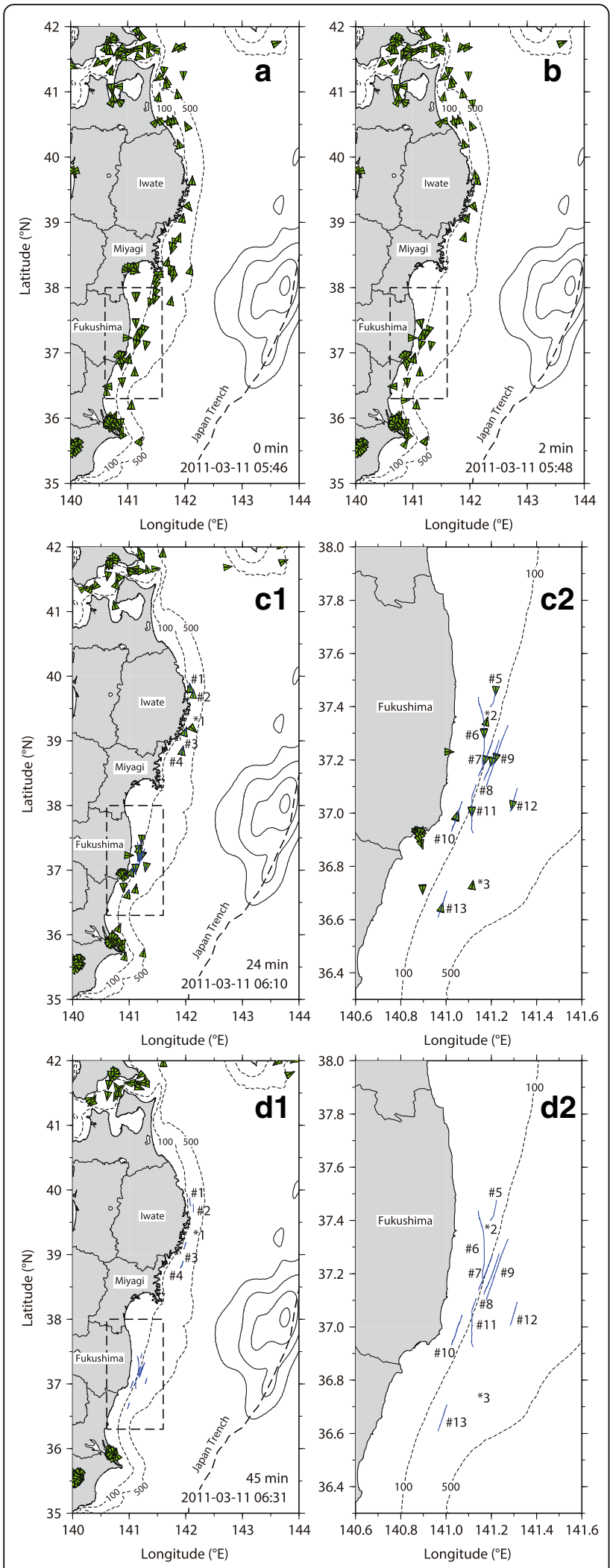

Fig. 2 Ship distributions derived from AIS data during the 2011 Tohoku tsunami. Distributions at a $0 \mathrm{~min}$, b $2 \mathrm{~min}, \mathbf{c} 24 \mathrm{~min}$, and $\mathbf{d} 45 \mathrm{~min}$ after the earthquake occurrence are shown. In $\mathbf{c}$ and $\mathbf{d}$, the right panel enlarges the rectangular area in the left panel, and blue lines trace ship tracks of 13 offshore vessels during 0-45 min after the earthquake occurrence (Table 1). Dashed isobaths of 100 and $500 \mathrm{~m}$ are added

$$
v=\mathrm{SOG} \sin (\mathrm{COG}-\mathrm{HDG}) \text {. }
$$

The tsunami current component in the HDG-normal direction is calculated at respective ships by using a tsunami simulation (Saito et al. 2014) with a validated tsunami source (Saito et al. 2011; Baba et al. 2017). We confirm notably good agreement between the ship velocity and the tsunami current in the HDG-normal direction for almost all the ships navigating offshore (Fig. 5). The velocity amplitudes are $\sim 1 \mathrm{~m} / \mathrm{s}$ or more and agree within the ship and the tsunami. Lag time of the velocity between them are mostly shorter than $\pm 2 \mathrm{~min}$. Thus, these AIS data are a clear proxy for tsunami currents with the equivalent amplitude in the HDG-normal direction.

\section{Measurable tsunami current}

We evaluate the relationship between the ship velocity and the tsunami current (Fig. 5) using an equation of motion of a movable floating body (Reddy and Swamidas 2013). The floating body is the navigating vessel. Since ship propulsion is likely imposed in the HDG direction in ordinary offshore navigation with autopilot, the equation of motion is applied in the HDG-normal direction in which only the external force works:

$$
\begin{aligned}
& m \frac{\partial v}{\partial t}=F_{D}+F_{I} \\
& F_{D}=\frac{1}{2} C_{D} \rho D L\left|v_{c}-v\right|\left(v_{c}-v\right) \\
& F_{I}=C_{M} \rho D L B \frac{\partial v_{c}}{\partial t}-\left(C_{M}-1\right) \rho D L B \frac{\partial v}{\partial t}
\end{aligned}
$$

Variables are summarized in Table 2. The driving forces are the drag force $\left(F_{D}\right)$ and the inertia force $\left(F_{I}\right)$ (O’Brien and Morison 1952; Dean and Dalrymple 1985). The ship velocity of Eq. (1), $v=$ SOG $\sin (\mathrm{COG}-\mathrm{HDG})$, is derived from observational AIS records (Fig. 5). D, $L$, and $B$ are given by static information from AIS data (Table 1). The equation is often rewritten as (Reddy and Swamidas 2013):

$$
\begin{aligned}
\left(m+m^{\prime}\right) \frac{\partial v}{\partial t}= & \frac{1}{2} C_{D} \rho D L\left|v_{c}-v\right|\left(v_{c}-v\right) \\
& +C_{M} \rho D L B \frac{\partial v_{c}}{\partial t}
\end{aligned}
$$

$m=\rho D L B$ 
Table 1 Static information of vessels derived from AIS data, except for gross tonnage, which was taken from MarineTraffic (https://www.marinetraffic.com/)

\begin{tabular}{|c|c|c|c|c|c|c|}
\hline$\overline{I D^{a}}$ & Vessel type & Gross tonnage & Draught $(\mathrm{m})$ & Length $(\mathrm{m})$ & Breadth $(\mathrm{m})$ & Note \\
\hline$\# 1$ & Cargo & 1658 & 5.0 & 98.52 & 15.0 & \\
\hline$\# 2$ & Cargo & 499 & 4.5 & 74.71 & 12.0 & \\
\hline \#3 & Tanker & 2998 & 6.4 & 104.81 & 15.5 & \\
\hline$\# 4$ & Cargo & 8566 & 5.3 & 119.5 & 20.4 & \\
\hline$\# 5$ & Tanker & 3319 & 4.5 & 99.8 & 15.8 & \\
\hline \#6 & Cargo & 14,790 & 7.5 & 167 & 30.2 & \\
\hline \#7 & Tanker & 748 & 4.5 & 74.99 & 11.5 & \\
\hline \#8 & Tanker & 3869 & 4.8 & 104.94 & 16.0 & \\
\hline \#9 & Cargo & 12,526 & 6.7 & 199 & 24.5 & \\
\hline \#10 & Tanker & 414 & N/A & 57.29 & 10.0 & \\
\hline \#11 & Cargo & 3692 & 6.3 & 115 & 20.0 & \\
\hline$\# 12$ & N/A & 499 & 4.0 & 76.2 & 13.0 & \\
\hline \#13 & Cargo & 748 & 5.0 & 83 & 14.0 & \\
\hline$* 1$ & Cargo & 77,871 & 9.9 & 273 & 47.0 & Clock of HDG may have an offset \\
\hline *2 & N/A & $\mathrm{N} / \mathrm{A}$ & 4.1 & 79 & 14.0 & $\mathrm{COG}=\mathrm{HDG}$ always declared \\
\hline *3 & N/A & 9510 & 5.8 & 133.16 & 19.6 & Cable-laying vessel, mostly stationary \\
\hline
\end{tabular}

${ }^{\mathrm{a}}$ Serial IDs are used in this paper instead of MMSIs to protect vessel privacy

$$
m^{\prime}=\left(C_{M}-1\right) \rho D L B
$$

$m$ is the mass of the ship that is equal to the water mass of the submerged portion of the vessel, but this is not always equal to the declared gross tonnage (Table 1 ). $m^{\prime}$ is the so-called added mass. Formulations similar to Eq. (3) were proposed to evaluate ship motion due to tsunami currents in ports and harbors (Ikeya et al. 2006). Here, we obtain:

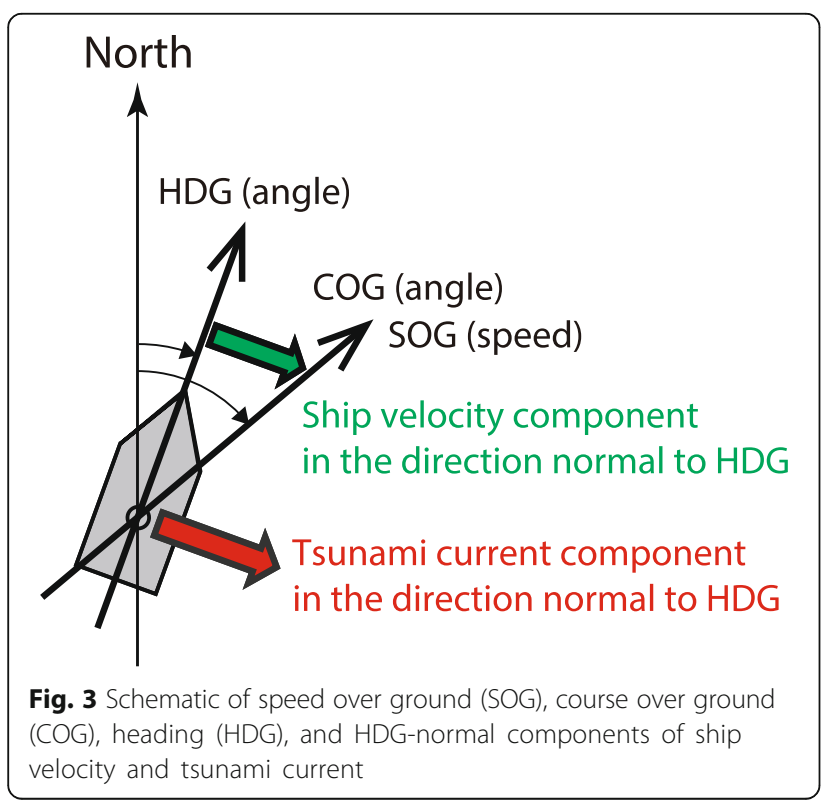

$$
\begin{aligned}
& \frac{\partial v^{\prime}}{\partial t}=-\lambda\left|v^{\prime}\right| v^{\prime}, \\
& v^{\prime}=v_{c}-v, \\
& \lambda=\frac{1}{2} \frac{C_{D}}{C_{M}} \frac{1}{B} .
\end{aligned}
$$

This differential equation can be solved as:

$$
\begin{aligned}
v^{\prime} & =\frac{1}{\lambda} \frac{1}{t+t_{r+}} \text { for } v^{\prime}>0, \\
v^{\prime} & =-\frac{1}{\lambda} \frac{1}{t+t_{r-}} \text { for } v^{\prime}<0,
\end{aligned}
$$

where $t_{r+}$ and $t_{r-}$ are arbitrary time constants. We suppose a motionless ship is forced by transient tsunami current $\left(v_{c}\right)$ in the HDG-normal direction, and consider the response of the ship velocity $(v)$ to the tsunami current. A proper condition is $v^{\prime}=v_{c}$ at $t=0$, and $v^{\prime}=0$ at $t=\infty$, which determines the constants. Then,

$$
\begin{aligned}
& v^{\prime}=\frac{v_{c}}{1+v_{c} \lambda t} \text { for } v^{\prime}>0, \\
& v^{\prime}=\frac{v_{c}}{1-v_{c} \lambda t} \text { for } v^{\prime}<0 .
\end{aligned}
$$

The profile of $v^{\prime}=v_{c}-v$ is shown in Fig. 6. It is understandable that $\left|v_{c}-v\right|$ will shrink to zero with an order of $t^{-1}$. We estimate $\lambda=1 / 40-1 / 120 \mathrm{~m}^{-1}$ from representative values of $C_{D} \sim 1$ with $C_{M} \sim 2$ (Dean and Dalrymple 1985), and $B=10-30 \mathrm{~m}$ (Table 1), and consider the 

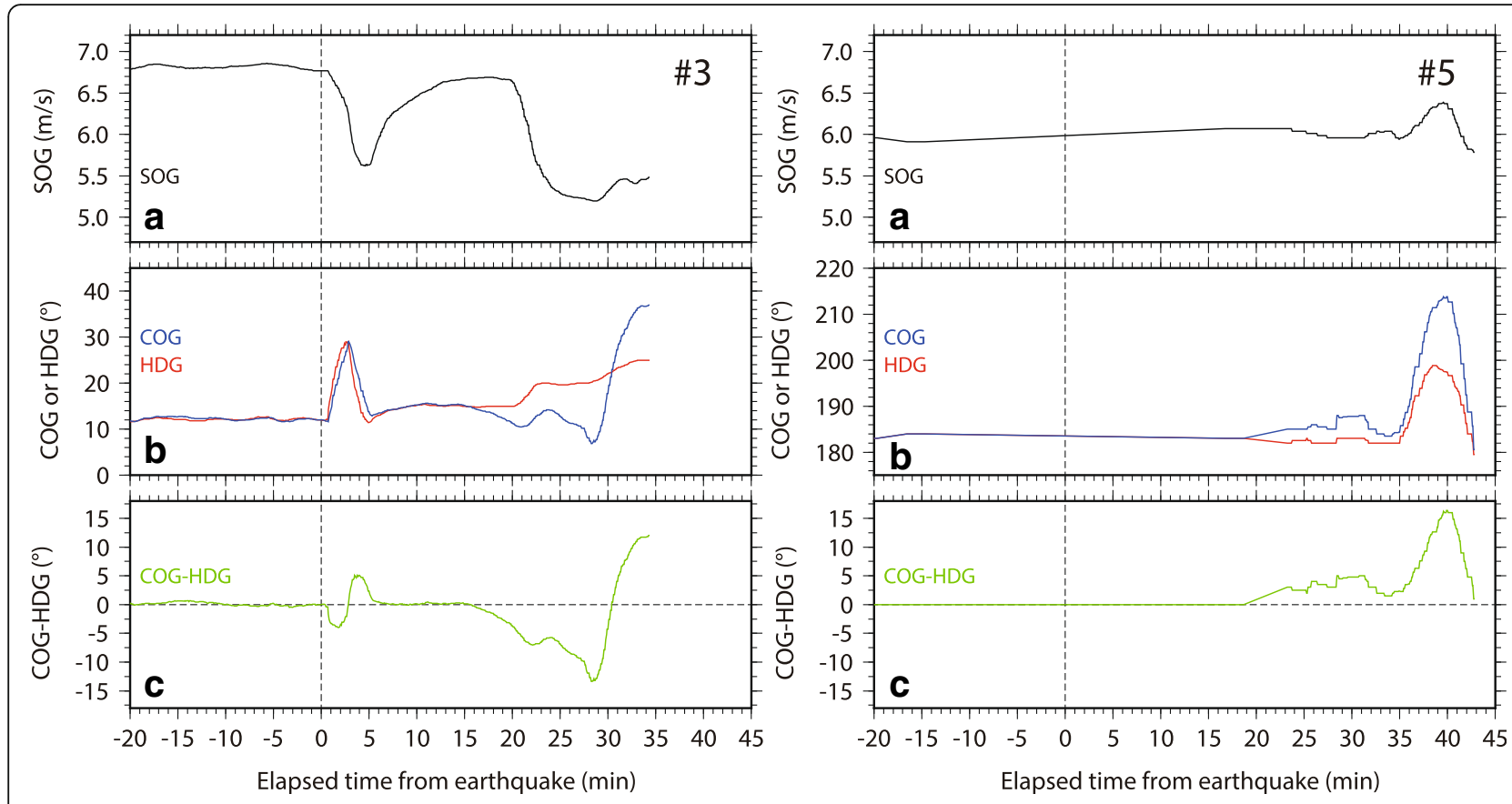

Fig. 4 a SOG, b COG/HDG, and c COG minus HDG of two selected ships (\#3 and \#5 in Fig. 2)

tsunami current as $v_{c} \sim 1 \mathrm{~m} / \mathrm{s}$ (Fig. 5). Once $T_{1 / 2}$ is the time that $v$ becomes greater than half of $v_{c}$ (Fig. 6), we obtain $T_{1 / 2}=1 / v_{c} \lambda=40-120 \mathrm{~s}$, indicating that the response time is effectively less than a few minutes.

An estimation of the ratio of drag force $\left(F_{D}\right)$ to inertia force $\left(F_{I}\right)$ known as the Keulegan-Carpenter number $\left(K_{C}\right)$ (Keulegan and Carpenter 1958; Dean and Dalrymple 1985) is:

$$
K_{C}=v_{c} \frac{T}{D} \propto \frac{F_{D}}{F_{I}} .
$$

We obtain a value as large as $K_{C}=10^{3}$ from the reasonable condition of $v_{c}=1 \mathrm{~m} / \mathrm{s}$ (tsunami current), $T=10^{3} \mathrm{~s}$ (tsunami period), and $D=10^{\circ} \mathrm{m}$ (submerged depth of vessel) (Fig. 5 and Table 1). Tsunamis involve long waves with longer periods than ordinary wind waves. It is reasonable that ships quickly respond to the drag force due to great tsunamis with such amplitudes and time scales (Heo et al. 2015).

Thus, we can understand the result of equivalent amplitude without a significantly biased lag time (less than \pm $2 \mathrm{~min}$ ) between the ship and tsunami velocity (Fig. 5). This interpretation is very useful since Eq. (1) will be a good proxy for measuring tsunami velocity. We may consider that the short lag time $(<\sim 120 \mathrm{~s})$ is mostly negligible compared to the great tsunami periods of $10^{3} \mathrm{~s}$. Then,

$$
\text { SOG } \sin (\mathrm{COG}-\mathrm{HDG})=v \approx v_{c} \text {. }
$$

Regarding this approximation, we need to consider $\lambda$ and $v_{c}$ instead of ship mass for the response time of the ship drift to the tsunami current (Eq. (6)). If $v_{c}$ is much smaller than $1 \mathrm{~m} / \mathrm{s}$, the response time will be effectively long. But what is important is great tsunamis as much as $\sim 1 \mathrm{~m} / \mathrm{s}$ or more. In such severe cases, the response will be more immediate and the approximation is more robust. If $B$ is larger, the response time will be longer. But a large portion $(\sim 80 \%)$ of the total number of vessels is occupied by small- and/or medium-sized $(<25,000$ gross tonnage) vessels that typically involve breadths of $<\sim$ $30 \mathrm{~m}$ (EMSA 2017). Thus, most AIS data in the current framework are already suitable as tsunami current meters, especially for great tsunamis.

\section{Tsunami inversion/forecast}

Once the tsunami velocity can be measured by the ship velocity component in the direction normal to the ship heading, it is worth carrying out inversion for real-time tsunami forecast to estimate source and tsunami height. Fuji et al. (2013) examined a tsunami inversion/forecast experiment using pseudo observation of tsunami current derived from coastal ocean radars (Hinata et al. 2011; Lipa et al. 2012; Benjamin et al. 2016). They employed the tsunami current instead of tsunami height for the inversion for the tsunami source. In the present study, we employ tsunami currents derived from the observational ship drifting (Fig. 5). Green's functions are composed by tsunami current components in the HDG-normal directions of the respective moving vessel by calculating from unit sources. Referring to our previous study (Inazu et al. 2016), we allocate unit sources with the same size/spacing and carry out the inversion/forecast. 


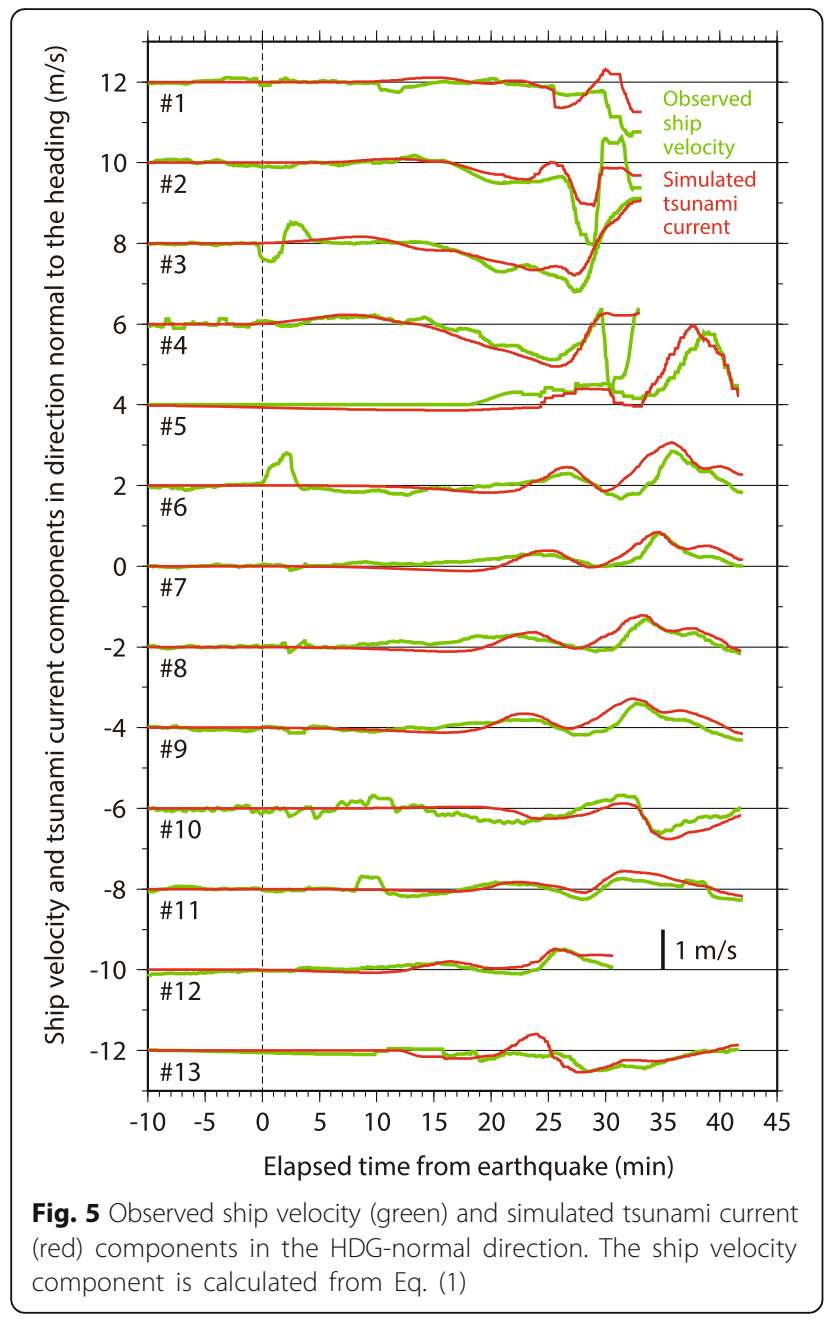

Table 2 Notation used in equations

\begin{tabular}{ll}
\hline Symbol & Notation \\
\hline$m$ & Mass of ship \\
$m^{\prime}$ & Added mass \\
$v$ & Ship velocity component in the HDG-normal direction \\
$v_{C}$ & Tsunami current component in the HDG-normal direction \\
$t$ & Time \\
$F_{D}$ & Drag force due to the tsunami current relative to the ship \\
$F_{l}$ & velocity \\
$C_{D}$ & Inertia force due to water acceleration with respect to the \\
$C_{M}$ & ship acceleration \\
$\rho$ & Coefficient of drag force \\
$D$ & Coefficient of inertia force \\
$L$ & Density of seawater \\
$B$ & Draught of ship \\
\hline
\end{tabular}

a

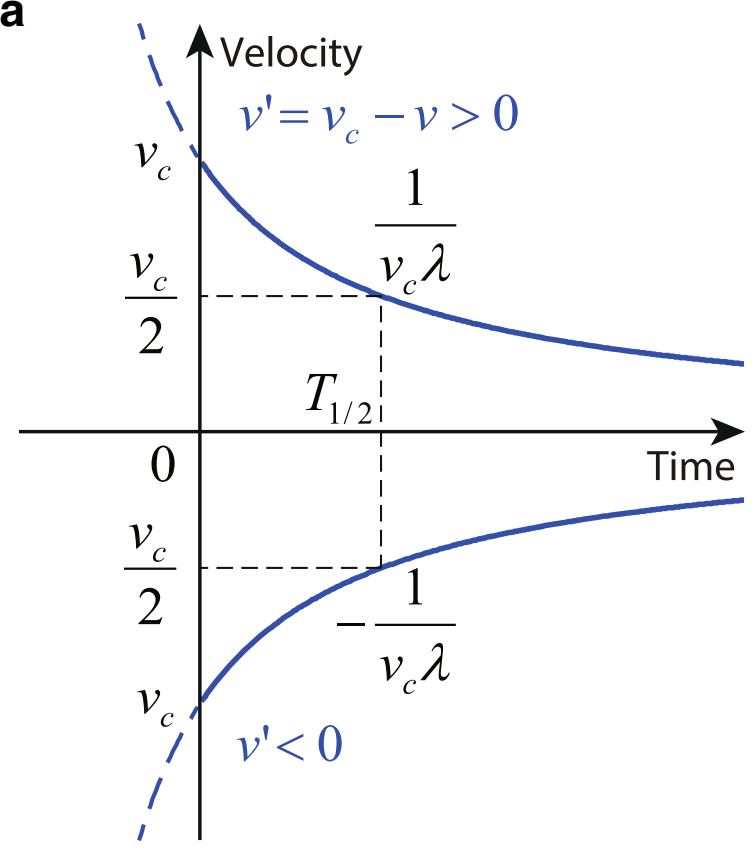

b

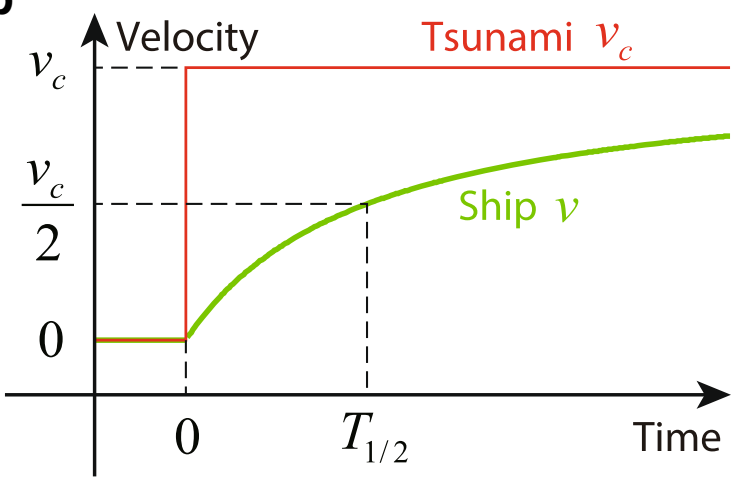

Fig. 6 Time evolution of $\mathbf{a}$ the solution of Eq. (6), and $\mathbf{b}$ tsunami velocity (red) and associated response of ship velocity (green). $T_{1 / 2}$ is time when $v=v_{c} / 2$

The inversion/forecast is carried out using the AIS data for $25 \mathrm{~min}$ after the earthquake occurrence (Fig. 7). The result can show mostly similar features in terms of both the source and the maximum tsunami height at the coast, compared to those from the validated source (Fig. 1). This indicates that ship velocity components in the HDG-normal direction of multiple ships derived from AIS records will be possibly useful for tsunami source estimation and forecast in addition to conventional tsunami height observations at fixed stations.

\section{Summary and remarks}

The AIS records of offshore navigating vessels were examined during the 2011 Tohoku tsunami. The AIS records from 13 vessels near the tsunami source showed 


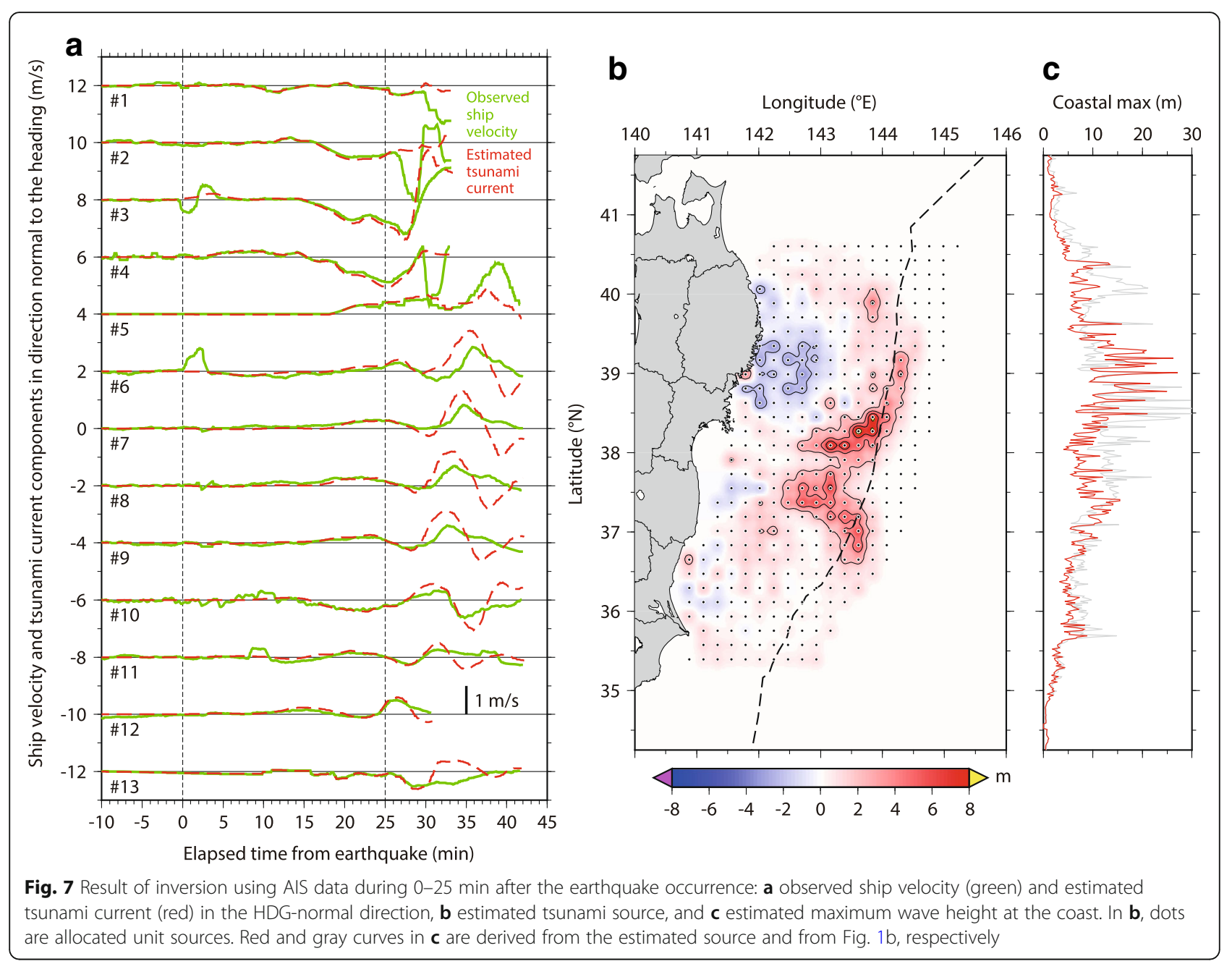

significant deviation of COG from HDG during the tsunami passage.

We compared the observed ship velocity component to the simulated tsunami velocity in the direction normal to the ship heading and confirmed good agreement in terms of amplitude $(\sim 1 \mathrm{~m} / \mathrm{s})$ with short lag times $(<\sim 2 \mathrm{~min})$ between them. Using an equation of motion of an offshore movable floating body, we obtained an analytical solution and understood that the ships immediately respond to the great tsunami current with the equivalent velocity amplitude in the HDG-normal direction.

This study indicates AIS data in the current framework can be used as a tsunami current meter in one direction for each vessel. We also showed that the observed tsunami velocity derived from the AIS data of multiple vessels during the 2011 Tohoku tsunami could be useful for tsunami source estimation and forecast.

The current AIS data are already provided via almost real-time successive transmission. The number of ships recognized by the AIS has been increasing year by year (UNCTAD 2017). We hope to exploit this large amount of data and expect the use of AIS data will become a new method for measuring and forecasting great tsunamis. Similar concepts of diverting information from crowd-sourced agents to Earth monitoring recently have been also applied to grasp earthquakes (Kong et al. 2016), winds, and ocean currents (Miyazawa et al. 2015).

Suitable methods for forecast will need to be developed. Assimilation/inversion of tsunami wave/current fields using moving point observations will be a possible way (Fujii and Satake 2007; Mulia et al. 2017). Such methods will be adopted also for assimilating wave height fields derived from satellite altimetry (Hamlington et al. 2012) and GNSS reflectometry (Stosius et al. 2011; Clarizia et al. 2016).

Efforts to ensure a good quality of AIS data should be made so that sophisticated forecast methods will work well (Table 1 and Additional file 1: Figure S1). The minimum requirement is to obtain the right records of the HDG and the GNSS ship position. SOG and COG are derived from GNSS. Ship officers can make adjustments so that HDG and COG are consistent and there is no substantial bias between them during offshore autopilot 
navigation in calm weather/ocean conditions. As long as based on Eq. (1), tsunami current evaluation may be difficult when SOG is very slow. We may easily pick up and omit very-slow-SOG vessels $(<\sim 0.5 \mathrm{~m} / \mathrm{s})$ when a great earthquake occurs. Further discussion will be necessary for automatically obtaining high-quality AIS data in real-time operation.

Although Japan already has dense offshore observatories for real-time tsunami monitoring and forecasting (Kawai et al. 2013; Kaneda et al. 2015; Yamamoto et al. 2016), most countries, in particular developing countries, will not be able to install and maintain similar dense offshore observatories mainly for economic reasons. Hopefully, the use of the AIS data will play a role in new tsunami monitoring/forecasting methods especially for developing countries such as those in Southeast Asia and South America. The density of vessels increases in coastal mega cities with highly economic activities. Tsunami disaster mitigation is especially important for such coastal mega cities due to their large populations. Maritime activities will continue as long as populations remain large. The use of the AIS data for tsunami current monitoring may be a sustainable way of tsunami disaster mitigation.

\section{Additional file}

Additional file 1: Figure S1. (a) SOG, (b) COG/HDG, and (c) COG minus HDG of selected ships (\#8 and \#11 for upper panels and *1 and *3 for lower panels). \#8 and \#11 are examples that were used for the tsunami current analysis (See also Fig. 4). ${ }^{*} 1$ and ${ }^{*} 3$ were not used due to the data quality issues noted in Table 1. (PDF $353 \mathrm{~kb}$ )

\section{Abbreviations}

AIS: Automatic Identification System; COG: Course over ground; HDG: Heading; IMO: International Maritime Organization; SOG: Speed over ground

\section{Acknowledgements}

We thank two anonymous reviewers for their constructive comments. The AIS data used in the present study were compiled by the IHS Maritime \& Trade.

\section{Funding}

This study was a part of the Mega-Tsunami Project of the University of Tokyo-Ocean Alliance supported by the Nippon Foundation. This study was partly supported by JSPS KAKENHI Grant Number 18K04654.

\section{Availability of data and materials}

Please contact the corresponding author for data requests.

\section{Authors' contributions}

DI designed and carried out the study and wrote the paper. TI, TW, TH, and YS contributed to the discussion on the behavior of drifting ships and tsunamis. TW provided detailed information on the AIS data. All authors read and approved the final manuscript.

\section{Competing interests}

The authors declare that they have no competing interest.

\section{Publisher's Note}

Springer Nature remains neutral with regard to jurisdictional claims in published maps and institutional affiliations.

\section{Author details}

'Department of Marine Resources and Energy, Tokyo University of Marine Science and Technology, 4-5-7 Konan, Minato, Tokyo 108-8477, Japan.

2UTokyo Ocean Alliance, The University of Tokyo, 7-3-1 Hongo, Bunkyo, Tokyo 113-0033, Japan. ${ }^{3}$ Graduate School of Frontier Sciences, The University of Tokyo, 5-1-5 Kashiwanoha, Kashiwa, Chiba 277-8563, Japan. ${ }^{4}$ Graduate School of Science, The University of Tokyo, 7-3-1 Hongo, Bunkyo, Tokyo 113-0033, Japan. ${ }^{5}$ Department of Civil and Environmental Engineering, National Defense Academy, 1-10-20 Hashirimizu, Yokosuka, Kanagawa 239-8686, Japan.

Received: 25 February 2018 Accepted: 2 July 2018

Published online: 07 August 2018

\section{References}

Allen RM, Gasparini P, Kamigaichi O, Bose M (2009) The status of earthquake early warning around the world: an introductory overview. Seismol Res Lett 80: 682-693. https://doi.org/10.1785/gssrl.80.5.682

Baba T, Allgeyer S, Hossen J, Cummins PR, Tsushima H, Imai K, Yamashita K, Kato T (2017) Accurate numerical simulation of the far-field tsunami caused by the 2011 Tohoku earthquake, including the effects of Boussinesa dispersion, seawater density stratification, elastic loading, and gravitational potential change. Ocean Modell 111:46-54. https://doi.org/ 10.1016/j.ocemod.2017.01.002

Benjamin LR, Flament P, Cheung KF, Luther DS (2016) The 2011 Tohoku tsunami south of Oahu: high-frequency Doppler radio observations and model simulations of currents. J Geophys Res Oceans 121:1133-1144. https://doi.org/10.1002/2015JC011207

Bernard E, Titov V (2015) Evolution of tsunami warning systems and products. Phil Trans R Soc A 373:20140371. https://doi.org/10.1098/rsta.2014.0371

Carson-Jackson J (2012) Satellite AIS_-developing technology or existing capability? J Nav 65:303-321. https://doi.org/10.1017/S037346331100066X

Clarizia MP, Ruf C, Cipollini P, Zuffada C (2016) First spaceborne observation of sea surface height using GPS-Reflectometry. Geophys Res Lett 43:767-774. https://doi.org/10.1002/2015GL066624

Dean RG, Dalrymple RA (1985) Wave forces. In: Water wave mechanics for engineers and scientists. Advanced series on ocean engineering, vol 2. World Scientific Publishing, Singapore, pp 212-260

Earles M, CANEUS Shared Small Satellites CSSP Workshop Committee (2010) International space-based AIS and data extraction backbone, high level requirements. CANEUS International, Montreal

European Maritime Safety Agency (EMSA) (2017) The world merchant fleet in 2016-statistics from Equasis. http://www.emsa.europa.eu/publications/technicalreports-studies-and-plans/item/472-annual-statistical-report-on-the-worldmerchant-statistics-from-equasisics-from-equasis.html. Accessed 15 June 2018

Falck C, Ramatschi M, Subarya C, Bartsch M, Merx A, Hoeberechts J, Schmidt G (2010) Near real-time GPS applications for tsunami early warning systems. Nat Hazards Earth Sys Sci 10:181-189. https://doi.org/10.5194/ nhess-10-181-2010

Foster JH, Brooks BA, Wang D, Carter GS, Merrifield MA (2012) Improving tsunami warning using commercial ships. Geophys Res Lett 39:L09603. https://doi. org/10.1029/2012GL051367

Fuji R, Hinata H, Fujii S, Takahashi T (2013) Influences of time integration on the accuracy of inversion based on ocean radar. J Jpn Soc Civil Eng B2 69:I_436I_440. doi:https://doi.org/10.2208/kaigan.69.I_436 (in Japanese with English abstract)

Fujii Y, Satake K (2007) Tsunami source of the 2004 Sumatra-Andaman earthquake inferred from tide gauge and satellite data. Bull Seismol Soc Am 97:S192-S207. https://doi.org/10.1785/0120050613

Hamlington BD, Leben RR, Godin OA, Gica E, Titov W, Haines BJ, Desai SD (2012) Could satellite altimetry have improved early detection and warning of the 2011 Tohoku tsunami? Geophys Res Lett 39:L15605. https:/doi.org/10.1029/ 2012GL052386

Heo S, Shigihara Y, Tada T, Hayashi K (2015) Hydraulic experiment and verification of numerical simulation for drifting and stranding multiple vessel by tsunami. J Jpn Soc Civil Eng B2 71:I_277-I_282. doi:https://doi. org/10.2208/kaigan.71.I_277 (in Japanese with English abstract) 
Hinata H, Fujii S, Furukawa K, Kataoka T, Miyata M, Kobayashi T, Mizutani M, Kokai T, Kanatsu N (2011) Propagating tsunami wave and subsequent resonant response signals detected by HF radar in the Kii Channel, Japan. Estuar Coast Shelf Sci 95:268-273. https://doi.org/10.1016/j.ecss.2011.08.009

Hirata K, Takayama H, Tsushima H, Hayashi Y, Iwase R, Baba T (2009) Integration of seafloor geodetic observation and offshore tsunami observation-toward researches on tsunami forecast. Proc 21st Ocean Eng Symp, OES21-181, Tokyo

Hoshiba M, Ozaki T (2014) Earthquake early warning and tsunami warning of the Japan meteorological agency, and their performance in the 2011 off the Pacific coast of Tohoku earthquake (Mw 9.0). In: Wenzel F, Zschau J (eds) Early warning for geological disasters. Springer, Heidelberg, pp 1-28. https:// doi.org/10.1007/978-3-642-12233-0_1

Igarashi Y, Hori T, Murata S, Sato K, Baba T, Okada M (2016) Maximum tsunami height prediction using pressure gauge data by a Gaussian process at Owase in the Kii Peninsula, Japan. Mar Geophys Res 37:361-370. https://doi.org/10. 1007/s11001-016-9286-Z

Ikeya T, Inagaki S, Asakura R, Fukuyama T, Fujii T, Ohmori M, Takeda T, Yanagisawa K (2006) Experimental and analytical study of impulsive forces by a drifter due to tsunami. J Coast Eng 53:276-280. https://doi.org/10.2208/ proce1989.53.276 (in Japanese)

Inazu D, Waseda T, Hibiya T, Ohta Y (2016) Assessment of GNSS-based height of multiple ships for measuring and forecasting great tsunamis. Geosci Lett 3: 25. https://doi.org/10.1186/s40562-016-0059-y

International Maritime Organization (IMO) (2002) Guidelines for the onboard operational use of shipborne Automatic Identification System (AIS). Resolution A.917(22), London

International Tsunami Information Center (ITIC) (2015) Pacific tsunami warning system: a half-century of protecting the Pacific, 1965-2015, 1st edn. Inoue Regional Center, National Oceanic and Atmospheric Administration, Honolulu

Kamigaichi O (2009) Tsunami forecasting and warning. In: Meyers RA (ed) Encyclopedia of complexity and systems science. Springer, New York, pp 9592-9618. https://doi.org/10.1007/978-0-387-30440-3_568

Kaneda Y, Kawaguchi K, Araki E, Matsumoto H, Nakamura T, Kamiya S, Ariyoshi K, Hori T, Baba T, Takahashi N (2015) Development and application of an advanced ocean floor network system for megathrust earthquakes and tsunamis. In: Favali P, Beranzoli L, De Santis A (eds) Seafloor observatories. Springer, Berlin, pp 643-662. https://doi.org/10.1007/978-3-642-11374-1_25

Katsumata A, Ueno H, Aoki S, Yoshida Y, Barrientos S (2013) Rapid magnitude determination from peak amplitudes at local stations. Earth Planets Space 65: 843-853. https://doi.org/10.5047/eps.2013.03.006

Kawai H, Satoh M, Kawaguchi K, Seki K (2013) Characteristics of the 2011 Tohoku tsunami waveform acquired around Japan by NOWPHAS equipment. Coast Eng J 55:1350008. https://doi.org/10.1142/S0578563413500083

Kawamoto S, Ohta Y, Hiyama Y, Todoriki M, Nishimura T, Furuya T, Sato Y, Yahagi T, Miyagawa K (2017) REGARD: a new GNSS-based real-time finite fault modeling system for GEONET. J Geophys Res Solid Earth 122:1324-1349. https://doi.org/10.1002/2016JB013485

Kawamura K, Laberg JS, Kanamatsu T (2014) Potential tsunamigenic submarine landslides in active margins. Mar Geol 356:44-49. https://doi.org/10.1016/j. margeo.2014.03.007

Keulegan GH, Carpenter LH (1958) Forces on cylinders and plates in an oscillating fluid. J Res Natl Bur Stand 60. https://doi.org/10.6028/jres.060.043

Kong Q, Allen RM, Schreier L, Kwon Y-W (2016) MyShake: a smartphone seismic network for earthquake early warning and beyond. Sci Adv 2:e1501055. https://doi.org/10.1126/sciadv.1501055

Lipa B, Isaacson J, Nyden B, Barrick D (2012) Tsunami arrival detection with high frequency (HF) radar. Remote Sens 4:1448-1461. https:/doi.org/10.3390/rs4051448

Liu X, Shiotani S, Sasa K (2015) An analysis of ship behavior induced by the Great East Japan Earthquake Tsunami based on AlS. In: Weintrit A (ed) Activities in navigation, marine navigation and safety of sea transportation. CRC Press, London, pp 119-123. https://doi.org/10.1201/b18513-19

Løvholt F, Pedersen G, Harbitz CB, Glimsdal S, Kim J (2015) On the characteristics of landslide tsunamis. Phil Trans R Soc A 373:20140376. https://doi.org/10. 1098/rsta.2014.0376

Maeda T, Obara K, Shinohara M, Kanazawa T, Uehira K (2015) Successive estimation of a tsunami wavefield without earthquake source data: a data assimilation approach toward real-time tsunami forecasting. Geophys Res Lett 42:7923-7932. https://doi.org/10.1002/2015GL065588

Makino $H$ (2013) Verification of the time tsunami attacked coasting ships using AIS—case of the 2011 Japan tsunami. J Earth Sci Eng 2:126-130. https://doi. org/10.17265/2159-581X/2013.02.005
Makinoshima F, Imamura F, Abe Y (2016) Behavior from tsunami recorded in the multimedia sources at Kesennuma City in the 2011 Tohoku tsunami and its simulation by using the evacuation model with pedestrian-car interaction. Coast Eng J 58:1640023. https://doi.org/10.1142/S0578563416400234

Mas E, Adriano B, Koshimura S (2013) An integrated simulation of tsunami hazard and human evacuation in La Punta, Peru. J Disast Res 8:285-295. https://doi.org/10.20965/jdr.2013.p0285

Matsuda N, Tomita T (2015) AlS data analysis on ships transported by the 2011 Tohoku tsunami and damage to port facilities by the ships. J Jpn Soc Civil Eng B2 71:I_1657-I_1662. doi:https://doi.org/10.2208/kaigan.71.I_1657 (in Japanese with English abstract)

Matsuda N, Tomita T, Yeom G-S, Takagawa T (2012) Numerical simulation on tsunami-transported large vessel with AIS data. J Jpn Soc Civil Eng B2 68:I_ 256-I_260. https://doi.org/10.2208/kaigan.68.I_256

McCaffrey R (2008) Global frequency of magnitude 9 earthquakes. Geology 36: 263-266. https://doi.org/10.1130/G24402A.1

Melgar D, Bock Y (2015) Kinematic earthquake source inversion and tsunami runup prediction with regional geophysical data. J Geophys Res Solid Earth 120:3324-3349. https://doi.org/10.1002/2014JB011832

Miyazawa Y, Guo X, Varlamov SM, Miyama T, Yoda K, Sato K, Kano T, Sato K (2015) Assimilation of the seabird and ship drift data in the north-eastern sea of Japan into an operational ocean nowcast/forecast system. Sci Rep 5: 17672. https://doi.org/10.1038/srep17672

Mulia IE, Hirobe T, Inazu D, Endoh T, Niwa Y, Tatehata H, Gusman AR, Waseda T, Hibiya T (2017) A reduced rank data assimilation for airborne measurements of a tsunami. Abstract HDS12-P07 presented at the JpGU-AGU Joint Meeting 2017, Makuhari, Japan, 20-25 May 2017. https://confit.atlas.jp/guide/event/ jpguagu2017/subject/E_HDS12-P07/detail?lang. Accessed 15 June 2018

National Research Council (NRC) (2011) Long-term reliability and sustainability of warning center operations. In: Tsunami warning and preparedness: an assessment of the U.S. tsunami program and the nation's preparedness efforts. The National Academies Press, Washington, DC, pp 163-205. https://doi.org/10.17226/12628

O'Brien MP, Morison JR (1952) The forces exerted by waves on objects. Trans AGU 33:32-38. https://doi.org/10.1029/TR033i001p00032

Rabinovich AB, Eblé MC (2015) Deep-ocean measurements of tsunami waves. Pure Appl Geophys 172:3281-3312. https://doi.org/10.1007/s00024-015-1058-1

Raby A, Macabuag J, Pomonis A, Wilkinson S, Rossetto T (2015) Implications of the 2011 Great East Japan Tsunami on sea defence design. Intl J Disast Risk Reduc 14:332-346. https://doi.org/10.1016/j.ijdrr.2015.08.009

Reddy DV, Swamidas ASJ (2013) Environmental forces on offshore structures. In: Essentials of offshore structures-framed and gravity platforms. CRC Press, Boca Raton, pp 337-418

Rong Y, Jackson DD, Magistrale H, Goldfinger C (2014) Magnitude limits of subduction zone earthquakes. Bull Seismol Soc Am 104:2359-2377. https:// doi.org/10.1785/0120130287

Ruhl CJ, Melgar D, Grapenthin R, Allen RM (2017) The value of real-time GNSS to earthquake early warning. Geophys Res Lett 44:8311-8319. https://doi.org/10. 1002/2017GL074502

Sagiya T (2004) A decade of GEONET: 1994-2003, the continuous GPS observation in Japan and its impact on earthquake studies. Earth Planets Space 56:xxix-xxli. https://doi.org/10.1186/BF03353077

Saito T, Inazu D, Miyoshi T, Hino R (2014) Dispersion and nonlinear effects in the 2011 Tohoku-Oki earthquake tsunami. J Geophys Res Oceans 119:5160-5180. https://doi.org/10.1002/2014JC009971

Saito T, Ito Y, Inazu D, Hino R (2011) Tsunami source of the 2011 Tohoku-Oki earthquake, Japan: inversion analysis based on dispersive tsunami simulations. Geophys Res Lett 38:L00G19. https://doi.org/10. 1029/2011GL049089

Satake K (2014) Advances in earthquake and tsunami sciences and disaster risk reduction since the 2004 Indian ocean tsunami. Geosci Lett 1:15. https://doi. org/10.1186/s40562-014-0015-7

Stosius R, Beyerle G, Hoechner A, Wickert J, Lauterjung J (2011) The impact on tsunami detection from space using GNSS-reflectometry when combining GPS with GLONASS and Galileo. Adv Space Res 47:843-853. https://doi.org/ 10.1016/j.asr.2010.09.022

Suga Y, Koshimura S, Kobayashi E (2013) Risk evaluation of drifting ship by tsunami. J Disast Res 8:573-583. https://doi.org/10.20965/jdr.2013.p0573

Sugawara D, Goto K (2012) Numerical modeling of the 2011 Tohoku-oki tsunami in the offshore and onshore of Sendai Plain, Japan. Sediment Geol 282:110123. https://doi.org/10.1016/j.sedgeo.2012.08.002 
Suppasri A, Muhari A, Futami T, Imamura F, Shuto N (2014) Loss functions for small marine vessels based on survey data and numerical simulation of the 2011 Great East Japan Tsunami. J Waterway Port Coast Ocean Eng 140: 04014018. https://doi.org/10.1061/(ASCE)WW.1943-5460.0000244

Suppasri A, Shuto N, Imamura F, Koshimura S, Mas E, Yalciner AC (2013) Lessons learned from the 2011 Great East Japan Tsunami: performance of tsunami countermeasures, coastal buildings, and tsunami evacuation in Japan. Pure Appl Geophys 170:993-1018. https://doi.org/10.1007/s00024-012-0511-7

Tang L, Titov W, Moore C, Wei Y (2016) Real-time assessment of the 16 September 2015 Chile tsunami and implications for near-field forecast. Pure Appl Geophys 173:369-387. https://doi.org/10.1007/s00024-015-1226-3

Terada Y, Kato T, Nagai T, Koshimura S, Imada N, Sakaue H, Tadokoro K (2015) Recent developments of GPS tsunami meter for a far offshore observations. In: Hashimoto M (ed) International symposium on geodesy for earthquake and natural hazards. International association of geodesy symposia, vol 145. Springer, Cham, pp 145-153. https://doi.org/10.1007/1345_2015_151

Tetley L, Calcutt D (2001) Electronic charts. In: Electronic navigation systems, 3rd edn. Butterworth-Heinemann, Oxford, pp 224-263

Tomita T, Yeom G-S, Ayugai M, Niwa T (2012) Breakwater effects on tsunami inundation reduction in the 2011 off the Pacific Coast of Tohoku Earthquake. J Jpn Soc Civil Eng B2 68:I_156-I_160. doi:https://doi.org/10.2208/kaigan.68.I_156 (in Japanese with English abstract)

Tournadre J (2014) Anthropogenic pressure on the open ocean: the growth of ship traffic revealed by altimeter data analysis. Geophys Res Lett 41:79247932. https://doi.org/10.1002/2014GL061786

Tsushima H, Hino R, Ohta Y, linuma T, Miura S (2014) tFISH/RAPiD: rapid improvement of near-field tsunami forecasting based on offshore tsunami data by incorporating onshore GNSS data. Geophys Res Lett 41:3390-3397. https://doi.org/10.1002/2014GL059863

Tsushima H, Hino R, Tanioka Y, Imamura F, Fujimoto H (2012) Tsunami waveform inversion incorporating permanent seafloor deformation and its application to tsunami forecasting. J Geophys Res Solid Earth 117: B03311. https://doi.org/10.1029/2011JB008877

Tsushima H, Hirata K, Hayashi Y, Tanioka Y, Kimura K, Sakai S, Shinohara M, Kanazawa T, Hino R, Maeda K (2011) Near-field tsunami forecasting using offshore tsunami data from the 2011 off the Pacific coast of Tohoku Earthquake. Earth Planets Space 63:821-826. https://doi.org/10.5047/eps.2011.06.052

United Nations Conference on Trade and Development (UNCTAD) (2017) Review of maritime transport 2017. http://unctad.org/en/Pages/Publications/Reviewof-Maritime-Transport-(Series).aspx. Accessed 15 June 2018

Wei Y, Chamberlin C, Titov W, Tang L, Bernard EN (2013) Modeling of the 2011 Japan tsunami: lessons for near-field forecast. Pure Appl Geophys 170:13091331. https://doi.org/10.1007/s00024-012-0519-z

Wei Y, Newman AV, Hayes GP, Titov W, Tang L (2014) Tsunami forecast by joint inversion of real-time tsunami waveforms and seismic or GPS data: application to the Tohoku 2011 tsunami. Pure Appl Geophys 171:3281-3305. https://doi.org/10.1007/s00024-014-0777-z

Willick WF (2014) Evaluating the effectiveness of a space-based AIS. Canad Young Scientist J (2):8-10. https://doi.org/10.13034/cysj-2014-009

Yamamoto N, Aoi S, Hirata K, Suzuki W, Kunugi T, Nakamura H (2016) Multi-index method using offshore ocean-bottom pressure data for real-time tsunami forecast. Earth Planets Space 68:128. https://doi.org/10.1186/s40623-016-0500-7

\section{Submit your manuscript to a SpringerOpen ${ }^{\circ}$ journal and benefit from:}

- Convenient online submission

- Rigorous peer review

- Open access: articles freely available online

- High visibility within the field

- Retaining the copyright to your article

Submit your next manuscript at $>$ springeropen.com 